\title{
Multi-indicator assessment of water environment in government environmental auditing
}

\author{
HE Gui-zhen ${ }^{1,2}$, LU Yong-long ${ }^{1, *}$, MA Hua ${ }^{1,2}$, WANG Xiao-long ${ }^{1,2}$ \\ 1. Research Centre for Eco-Environmental Sciences, Chinese Academy of Sciences, Beijing 100085, China. E-mail: heguizh@yahoo.com.cn \\ 2. Graduate University of the Chinese Academy of Sciences, Beijing 100039, China
}

Received 20 August 2006; accepted 24 November 2006

\begin{abstract}
This study focused on a multi-indicator assessment methodology for governmental environmental auditing of water protection programs. The environmental status of Wuli Lake in China was assessed using the global indicators (driver-status-response) developed by the Commission on Sustainable Development, and four additional indicators proposed by the author: water quality, pollution load, aquatic ecosystem status, and lake sediment deposition. Various hydrological, chemical, biological and environmental parameters were used to estimate the values of the indicators for assessment of environmental status of the lake based on time series data sets for twenty years. The indicators proposed can be customized to meeting the needs for particular assessment of water protection programs. This method can be used to evaluate the performance of national environmental protection programs and provide technical support for environmental auditors.
\end{abstract}

Key words: environmental auditing; environmental indicators; pollution load; lake ecosystem; state assessment

\section{Introduction}

China has many freshwater lakes, which are important for the sustainable development of local areas. The lakes have various functions including storaging flood water, supplying drinking water, irrigation, fish farming and recreation. Since the 1980 s, population pressures have increased and the agricultural and industrial production around the lakes has intensified (Yang et al., 2003). These resulted in a rapid increase of nutrient input, which caused major ecological deterioration in the lakes (Qin and Luo, 2004; SEPA, 2004). In order to control the negative changes of lake water, some policies, plans and programs were implemented by the central and local governments (SEPA website). The performance of different policies, plans and programs is an increasing consideration of the government and the public. Government environmental auditing is an important tool for supervising, certifying and evaluating the performance of environmental policies, plans and programs (Bernard and Landis, 1997; INTOSAI, 2001; Wang et al., 2006). However, performance evaluation is impossible without the information from past and present monitoring, as well as science-based water resources decision-making (Jones et al., 2001).

Various indicators can be used for assessment of river and lake environment quality. The US Environmental

Project supported by the International Project between The Netherlands Royal Academy of Arts and Sciences and Chinese Academy of Sciences (No. 04CDP014) and the National Natural Science Foundation of China (No. 40471130).*Corresponding author. E-mail: yllu@cashq.ac.cn.
Protection Agency has proposed the water quality criteria (USEPA, 1986) and minimum streamflow criteria (Tennant, 1976; US Fish and Wildlife Service, 1980) for assessing ecosystem status. The Grand Canyon Monitoring and Research Center (GCMRC) of America monitored physical, chemical, and biological parameters to evaluate the status of environmental quality in Lake Powell on the Grand Canyon River since 1965 (GCMRC, 1999). Bain et al. (2000) reviewed the assessment and evaluation methods for aquatic ecosystem protection and restoration. These methods include the EPT index (Bode and Novak, 1995; Novak and Bode, 1992), the index of biotic integrity (Karr, 1991; Karr and Dudley, 1981), the watershed habitat evaluation and biotic integrity protocol (Goforth, 1999) and the integrated river aquifer simulation model (Loucks, 1995; Loucks et al., 1996). It should be emphasized that most of the above mentioned indicators focused on state evaluation and quality description. There were few connections with governmental policies and programs. The Commission on Sustainable Development (CSD) proposed the Driving Force-State-Response (DSR) framework of indicators for the evaluation of many issues pertaining to sustainable development (Program, 1995). DSR provided a link between policy and quality, yet it mainly considered macro aspects and was difficult to relate one state with specific policy. However, environmental auditing paid more attention to post-project or post-policy evaluation. An important question is how to combine the micro data with macro decisions. There is an urgent need for integrated indicators that can help to screen processes in different 
areas at the local, national and regional level (OECD, 1997).

The main aim of this study was to give assessment indicators for lake water in environmental auditing by using those put forward by Kondratyev et al. (2002). In addition to the indicators proposed by the CSD, new indicators were proposed, including external loads, water quality parameters, status of the aquatic ecosystem, and sediment. Then these indicators were applied to Wuli Lake, Jiangsu Province, China. The environmental state of Wuli Lake with its catchment and connected rivers, and the changes in the last two decades were evaluated using these environmental indicators. These indicators can be used by decision-makers and auditors for auditing the effectiveness of environmental policies, plans and programs.

\section{Study area, indicators framework and data sources}

\subsection{Study area}

Wuli Lake (Fig.1) is a part of the third biggest freshwater lake in China-Taihu Lake. The importance of the lake aquatic system is recognized by government officials and the public for sustainable development of Wuxi City, Jiangsu Province. The average depth is $1.8 \mathrm{~m}$. Its water surface area is $8.6 \mathrm{~km}^{2}$, and its volume is $8.4 \times 10^{6} \mathrm{~m}^{3}$. The drainage area is over $50 \mathrm{~km}^{2}$. It is connected to the Liangxi River, Mali Gang, Caowang Jing and others. The average annual rainfall is $1112 \mathrm{~mm}$, and average annual runoff is $4.85 \times 10^{6} \mathrm{~m}^{3}$ (SIDRI, 2002).

\subsection{Indicator framework}

To evaluate water quality based on the govermental policies, plans and programs were implemented, an anal-

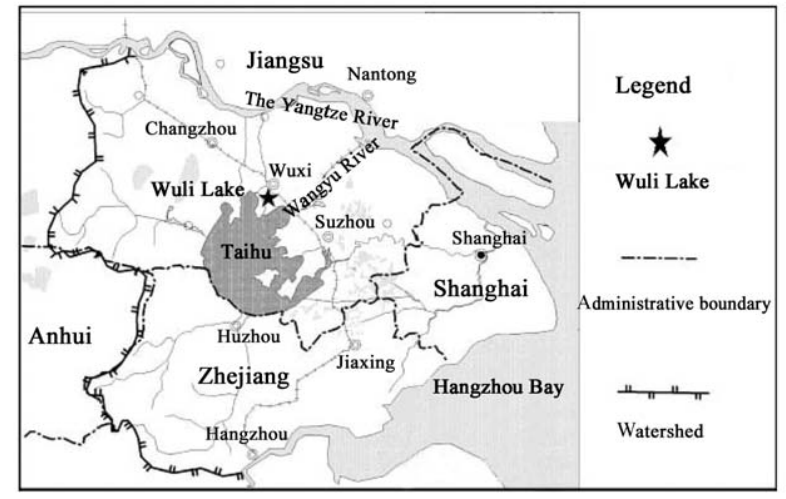

Fig. 1 Wuli Lake map. ysis using the indicators proposed by the CSD and other indicators can be made to indicate the quality and supply of freshwater resources. The framework of indicators is shown in Fig.2.

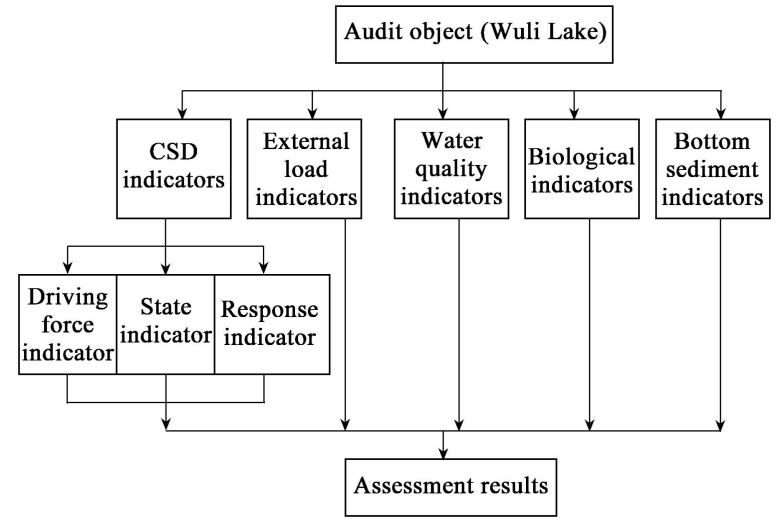

Fig. 2 Framework of assessment indicators.

\subsection{Data types and sources}

As environmental auditing is a check and verification process, the audit data and information were collected from the audited organization and the third party. With regard to the governmental audits, the audit data should be authoritative and objective. Data was obtained through document analysis, literature review, and face-to-face interview. The major data sources are the environmental statistical database of the Environmental Monitoring Center of Environmental Protection Bureau of Wuxi City (WXEPB), the Wuxi City Statistical Yearbook, the Annual Environmental Quality Report of Wuxi City, and other governmental documents. The hydrochemical data were obtained from the sampling stations located in Wuli Lake.

\section{Case study results}

\subsection{Evaluation of the state of water resources using indicators proposed by CSD}

There are three types of indicators proposed by the CSD, including driving force indicators, state indicators, and response indicators.

The driving force indicators are $\mathrm{ID}_{1}, \mathrm{ID}_{2}$ and $\mathrm{ID}_{3}$. The state indicators include $\mathrm{IS}_{1}, \mathrm{IS}_{2}$ and $\mathrm{IS}_{3}$. The response indicators present here are $\mathrm{IR}_{1}, \mathrm{IR}_{2}, \mathrm{IR}_{3}$, and dimensionless indicators (indices) $\mathrm{IR}_{2} / \mathrm{IR}_{1}, \mathrm{IR}_{3} / \mathrm{IR}_{1}, \mathrm{IR}_{3} / \mathrm{IR}_{2}$.

The values of driving force indicators such as $\mathrm{ID}_{1}$ and $\mathrm{ID}_{2}$ are presented in Table 1 . As the study area has large

Table 1 Driving force indicators (ID) of water use in Wuli Lake

\begin{tabular}{lllllllllllll}
\hline Indicator & 1985 & 1990 & 1995 & 1996 & 1997 & 1998 & 1999 & 2000 & 2001 & 2002 & 2003 & 2004 \\
\hline $\mathrm{AR}$ & 4.9 & 5.1 & 4.8 & 5.2 & 4.6 & 6.5 & 6.2 & 5.1 & 4.9 & 4.7 & 4.9 & 4.8 \\
$\mathrm{ID}_{1}$ & 1.2 & 1.3 & 1.2 & 1.4 & 1.1 & 1.6 & 1.5 & 1.3 & 1.2 & 1.0 & 1.2 & 1.2 \\
$\mathrm{ID}_{2}$ & 15.2 & 16.2 & 10.5 & 10.9 & 9.5 & 9.7 & 9.3 & 8.5 & 6.8 & 3.5 & 2.8 & 3.1 \\
$\mathrm{ID}_{3}$ & 135 & 175 & 231 & 262 & 225 & 219 & 284 & 266 & 149 & 153 & 164 & 168 \\
\hline
\end{tabular}

AR: annual runoff $\left(\times 10^{6} \mathrm{~m}^{3}\right)$; ID 1 : the annual withdrawal of ground water as a percentage of available water $(\%)$; ID 2 : the annual withdrawals of surface water as a percentage of the surface water resources $(\%) ; \mathrm{ID}_{3}$ : domestic consumption of water per capita (L/(person·d)). Resources: Wuxi City Statistical Yearbook. 
resources of surface water, the problem of supplying the population with drinking water can be solved by using surface water. However, this is not practicable for Wuxi City due to the critical water pollution. Therefore, more treatment measures must be considered as a promising solution for long-term water supply programs. At present more attention must be paid to surface water protection and its rational use.

The values of the state indicators such as $\mathrm{IS}_{1}, \mathrm{IS}_{2}$, and $\mathrm{IS}_{3}$ are given in Table 2 (China, GB5749-85; GB38382002).

Taking into account the average values of bacteriological indicators, the surface water quality of Wuli Lake and its catchment basin is of class III and its connected river quality is class II. Sometimes the values of the coli-index increased to a dangerous level. High concentrations of faecalcoliform reflect the deterioration of epidemiological quality in the polluted water area and pose a serious hazard to human health.

The surface water is characterized by an increased content of organic substances. $\mathrm{BOD}_{5}$ values beyond the critical ones ( $10 \mathrm{mg} \mathrm{O}_{2} / \mathrm{L}$ ) have been observed every year in this area, lower than the class $\mathrm{V}$ of the China national standard water quality (GB3838-2002). The highest level of organic pollution of surface waters was registered in the connected rivers $\left(38.3 \mathrm{mg} \mathrm{O}_{2} / \mathrm{L}\right)$.

The values of response indicators such as $\mathrm{IR}_{1}, \mathrm{IR}_{2}, \mathrm{IR}_{3}$ and dimensionless indicators (indices) $\mathrm{IR}_{2} / \mathrm{IR}_{1}, \mathrm{IR}_{3} / \mathrm{IR}_{1}$, $\mathrm{IR}_{3} / \mathrm{IR}_{2}$ are presented in Table 3. Obviously, the higher the $\mathrm{IR}_{2} / \mathrm{IR}_{1}$ and the lower $\mathrm{IR}_{3} / \mathrm{IR}_{1}$ are, the better the water policies, plans and programs.

From the beginning of the 1990s, the eighth, ninth and tenth Five-Year Plan for Taihu Lake pollution control were developed and implemented successively. The Integrated Pollution Control Project for Wuli Lake was carried out from 2002 to 2004, and some 40 domestic wastewater treatment plants were built or expanded by the end of 2005

Table 2 State indicators (IS) of water quality

\begin{tabular}{llll}
\hline Region & IS $_{1}$ & IS $_{2}$ & IS $_{3}$ \\
\hline Wuli Lake & 8.4 & III $(<10000)$ & III-V (3.3-9.5) \\
Connected rivers & 692.0 & II $(<2000)$ & IV-V $(4.8-12.0)$ \\
Catchment basin & 4.9 & III $(<10000)$ & I-V $(2.8-10.1)$ \\
\hline
\end{tabular}

IS $_{1}$ : surface water reserves $\left(\times 10^{6} \mathrm{~m}^{3}\right)$; IS 2 : class of water quality by concentration of faecalcoliform in freshwater body (coli-index, number of cells per liter); IS $_{3}$ : class of water quality by biochemical oxygen demand $\left(\mathrm{BOD}_{5} \mathrm{mg} \mathrm{O}_{2} / \mathrm{L}\right.$ ) in water body. Resources: Environmental Monitoring Center of Wuxi City EPB.
(Wang et al., 2006). As a consequence, the water quality of the lake was improved to some extent (Chen, 1999). As shown in Table 3, the treatment rate of wastewater $\left(\mathrm{IR}_{2} / \mathrm{IR}_{1}\right)$ was increasing while the non-treatment rate of wastewater $\left(\mathrm{IR}_{3} / \mathrm{IR}_{1}\right)$ decreased from 1985 to 2004 . The tendency indicates an improved effectiveness of the sewage treatment in the study area.

\subsection{External load on Wuli Lake and water body of its drainage basin}

The basic components of the external load are point source and non-point source pollutants. The external load on a water body is a constant factor to form the chemical composition of the water and bottom sediment. The water quality and ecological state of the aquatic system are governed to a great extent by the level of external load (Vollenweider, 1968). Changes in value of external load may be used as a basis for the assessment of the efficiency of water protection measure.

The following load indicators have been estimated for a lake drainage basin: $\mathrm{IL}_{1}, \mathrm{IL}_{2}$ and $\mathrm{IL}_{3}$. The external load of point source and non-point source pollutants in Wuli Lake was very high (Chen, 1999; Fan, 1996). $\mathrm{IL}_{1}, \mathrm{IL}_{2}$ and $\mathrm{IL}_{3}$ are presented in Table 4 because phosphorus is one of the most important limited factors of water eutrophication in Wuli Lake (Jiao and Li, 2005).

As shown in Table 4, the values of all three indicators increased at first (1985-2001) and then decreased (after 2002). Though the augment of the treatment plants power was observed during the last two decades (Table 3), the increase in the external load on Wuli Lake could be explained by the rapid development of industrial and agricultural activities. The most important share of external load on Wuli Lake is municipal and aquaculture wastewater inflow which accounts for $70 \%-80 \%$ of the total. The reduction trend since 2002 can be regarded as a sign of effectiveness of the treatment program. The maximal decrease was observed in 2004.

The dynamics of phosphorus load on Wuli Lake are shown in Fig.3. From 1985 to 2001, the phosphorus inflow to Wuli Lake from the catchment gradually increased, and there were some years when phosphorus load on the lake was extremely high. The reduction of pollutants load after 2002 was mostly the result of efficient water pollution treatment. Decrease of load on drainage basin leads to a decrease of load on Wuli Lake. The loads of the other chemicals such as nitrogen and phosphorous showed similar temporal dynamics.

Table 3 Response indicators (IR) of waste water treatment

\begin{tabular}{|c|c|c|c|c|c|c|c|c|c|c|c|c|}
\hline Indicator & 1985 & 1990 & 1995 & 1996 & 1997 & 1998 & 1999 & 2000 & 2001 & 2002 & 2003 & 2004 \\
\hline $\mathrm{IR}_{1}$ & 215 & 346 & 457 & 468 & 489 & 523 & 684 & 842 & 831 & 585 & 361 & 152 \\
\hline $\mathrm{IR}_{2}$ & 24 & 41 & 55 & 63 & 74 & 85 & 137 & 233 & 240 & 178 & 155 & 72 \\
\hline $\mathrm{IR}_{3}$ & 52 & 78 & 89 & 98 & 102 & 92 & 128 & 161 & 155 & 106 & 53 & 18 \\
\hline $\mathrm{IR}_{2} / \mathrm{IR}_{1}$ & 0.11 & 0.11 & 0.12 & 0.14 & 0.15 & 0.16 & 0.20 & 0.27 & 0.29 & 0.31 & 0.42 & 0.47 \\
\hline $\mathrm{IR}_{3} / \mathrm{IR}_{1}$ & 0.24 & 0.22 & 0.19 & 0.21 & 0.20 & 0.17 & 0.19 & 0.19 & 0.18 & 0.18 & 0.15 & 0.12 \\
\hline $\mathrm{IR}_{3} / \mathrm{IR}_{2}$ & 2.2 & 1.9 & 1.6 & 1.5 & 1.3 & 1.1 & 0.9 & 0.7 & 0.6 & 0.6 & 0.3 & 0.3 \\
\hline
\end{tabular}

$\mathrm{IR}_{1}$ : the total discharge of waste water $\left(\times 10^{4} \mathrm{~m}^{3} / \mathrm{a}\right) ; \mathrm{IR}_{2}$ : partly treated wastewater $\left(\times 10^{4} \mathrm{~m}^{3} / \mathrm{a}\right) ; \mathrm{IR}_{3}$ : non-treated wastewater $\left(\times 10^{4} \mathrm{~m}^{3} / \mathrm{a}\right) ; \mathrm{IR}_{2} / \mathrm{IR}_{1}$ : the treatment rate of wastewater; $\mathrm{IR}_{3} / \mathrm{IR}_{1}$ : the non-treatment rate of wastewater; $\mathrm{IR}_{3} / \mathrm{IR}_{2}$ : the proportion of non-treated wastewater to treated waters. Resources: Environmental Monitoring Center of Wuxi City EPB; Wuxi City Statistical Yearbook. 
Table 4 Indicators of TP load (IL) on Wuli Lake drainage basin

\begin{tabular}{|c|c|c|c|c|c|c|c|c|c|c|c|c|}
\hline Indicator & 1985 & 1990 & 1995 & 1996 & 1997 & 1998 & 1999 & 2000 & 2001 & 2002 & 2003 & 2004 \\
\hline $\mathrm{IL}_{1}$ & 38.6 & 47.4 & 62.6 & 67.0 & 72.7 & 73.6 & 65.7 & 72.7 & 77.5 & 73.6 & 56.6 & 46.5 \\
\hline $\mathrm{IL}_{2}$ & 684 & 759 & 1273 & 1656 & 1376 & 1706 & 1635 & 1506 & 1601 & 804 & 513 & 31 \\
\hline $\mathrm{IL}_{3}$ & 0.055 & 0.048 & 0.060 & 0.070 & 0.051 & 0.066 & 0.061 & 0.058 & 0.059 & 0.040 & 0.026 & 0.014 \\
\hline
\end{tabular}

$\mathrm{IL}_{1}$ : TP load of basin area $\left(\mathrm{kg} / \mathrm{km}^{2}\right)$; $\mathrm{IL}_{2}$ : TP load of surface water $\left(\times 10^{-6} \mathrm{~kg} / \mathrm{m}^{3}\right)$; IL 3 : TP load per capita (kg/person). Resources: Wuxi City EPB; Wuxi City Statistical Yearbook.

\subsection{Water quality indicators}

The assessment of water quality can be carried out by comparing the observed concentration of pollutants with the standard concentration $\left(S_{i}\right)$ as well as by using the integrated index of water pollution (Ma, 1997; SEPA, 2002).

$P=\frac{1}{n} \sum_{i=1}^{n} \frac{C_{i}}{S_{i}}=\frac{1}{n} \sum_{i=1}^{n} P_{i}$

where, $P$ is integrated index of water pollution (below it is named $P$ value), $C_{i}$ is the mean annual concentration of a pollutant, and $n$ is the number of pollutant used for the calculation, $i=1,2,3 \ldots \ldots n, P_{i}=C_{i} / S_{i}$, it is a index of water pollution for $i$ pollutant .

In order to calculate the integrated index of water pollution ( $P$ value), five variables were used, including chemical oxygen demand (COD), total phosphorus (TP), total nitrogen (TN), chlorophyll- $a(\mathrm{Chl}-a)$ and volatile hydroxybenzene. An increased tendency of $P$ value can be seen during the last two decades in Fig.4. This fact testifies that the problem of pollution, along with eutrophication, became very serious. As a result of greatly increased input of organic pollutants and nutrients, the saprobity and toxicity of Wuli Lake water have also increased. According to sanitary-chemical analysis data, water in different parts of the lake is contaminated differently by

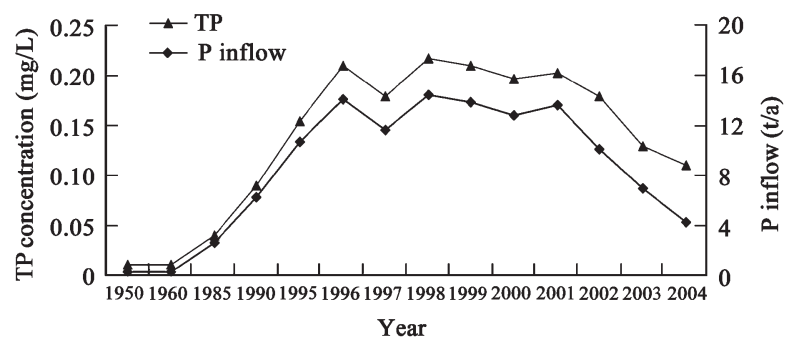

Fig. 3 Concentration and riverine inflow of total phosphorus in Wuli Lake.

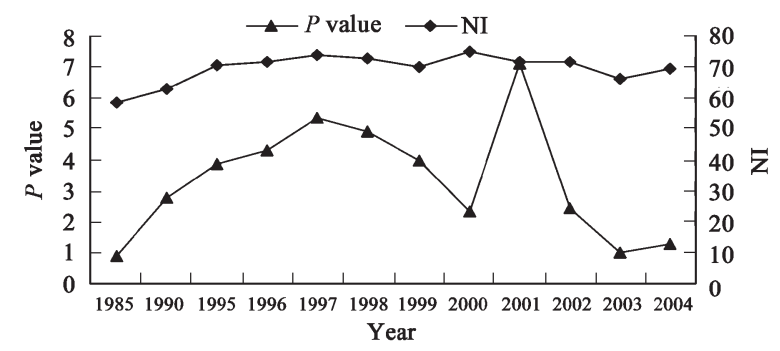

Fig. 4 Integrated index of water pollution $(P$ value) and eutrophication index (NI). organic pollutants, nitrogen and phosphorus (Fan et al., 1992; Fan, 1996; Gu and Lu, 2004; SIDRI, 2002; Yang and Sun, 2001). Although $P$ value has tended to decrease since 2002, long lasting, high concentration pollutants make the water purification process rather slow.

Since eutrophication is the key problem in the study area, the eutrophication index was calculated for the establishment of water management plans and assessment of the effectiveness of implemented programs (Jin, 1990, 2001; Jin et al., 1990; Jin and Tu, 1990; Fan and Chen, 1998; Jiao and Li, 2005). Assessment of Wuli Lake trophic level based on COD, TP, TN, Chl- $a$ and transparency value (SD) shows that the continuous increase of eutrophication has gradually lead Wuli Lake to a severe eutrophic lake in the last twenty years, and at present Wuli Lake is in a medium eutrophic state due to integrated treatment (Fig.4).

\subsection{Biological indicators of lake ecosystem}

The protection of water ecosystems is an essential part of the planning and management process. The evaluation of the state of an ecosystem must consider changes in major biotic components and in modes of their interaction (Bain and Loucks, 1999; Harig and Bain, 1998). As criteria for the indication of the impact of human activities on the ecosystem of a lake, the following main biotic parameters can be recommended for consideration: the primary production and decomposition rate of organic matter, the Shannon-Wiener index of species diversity of flora and fauna, number of dominants and population densities of different taxonomic groups in planktonic and benthic communities, and indices of molecular ecotoxicology.

Recently, a new integrated index (IP) for water quality evaluation based on structural characteristics of zoobenthos was proposed by Balushkina (1997) based on four well known indices.

Long-term investigation of Wuli Lake since 1951 has shown that the concentrations of phosphorus and nitrogen in the water were the main factors that determined primary production, species composition of phytoplankton and, ultimately, the trophic status of Wuli Lake (Fan, 1996; Nanjing Institute of Geography, 1965, 1982; Zhu, 1959).

The species composition of hydrophyte in Wuli Lake has notably changed since the 1950s. In 1951, aquatic macrophyte covered the entire water surface of Wuli Lake, and the dominant plants were reed and water chestnut. From the beginning of the 1980s, macrophyte area has decreased and micro-phytoplankton increased, especially Oscillatoria sp. and Mersmopedia sp. (algae with high pollution index) (Bai, 1962; Bao, 1983; SIDRI, 2002). The excessive discharge of phosphorus and nitrogen could cause algae bloom. The biomass of phytoplankton in Wuli 
lake has been observed (Fig.5), indicating the algae bloom incidents in 1990, 1994 and 1997.

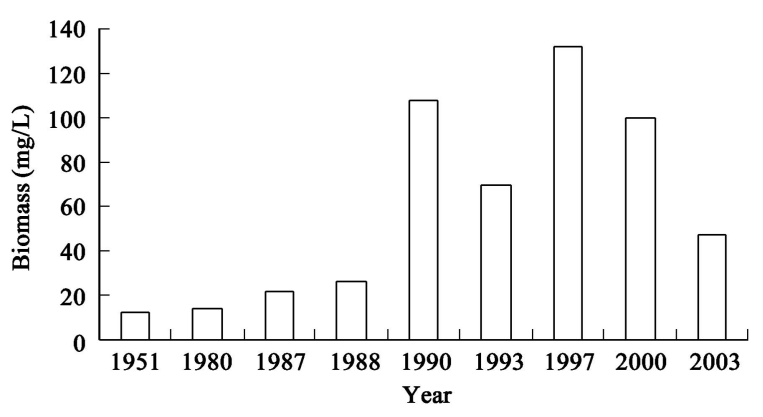

Fig. 5 Biomass of phytoplankton in Wuli Lake.

Zooplankton is mainly considered as an indicator of saprobity or trophic state of a water body. Moreover, zooplankton indices based on taxonomic composition, size distribution and trophic level may be of high informative potential (Andronikova, 1996). Zooplankton showed very high variation of the average numbers and biomass values since the 1950s (Fan, 1996; Fan et al., 1992; Nanjing Institute of Geography, 1965, 1982; Zhu, 1959). As shown in Table 5, zooplankton communities have demonstrated distinct reduction.

Table 5 Variation of zooplankton species in Wuli Lake

\begin{tabular}{lllllll}
\hline Community & 1951 & 1981 & 1984 & 1987 & 1996 & 2002 \\
\hline Protozoa & 60 & 21 & 13 & 13 & 5 & 4 \\
Rotifera & 33 & 32 & 29 & 16 & 7 & 7 \\
Cladocera & 18 & 18 & 16 & 10 & 5 & 3 \\
Copepoda & 17 & 17 & 8 & 5 & 4 & 3 \\
Total & 128 & 83 & 66 & 44 & 22 & 17 \\
\hline
\end{tabular}

Resources: SIDRI, 2002.

Structural and numerical data on macrozoobenthos provide good indication of changes in the ecosystem. Communities of benthic invertebrates in Wuli Lake have been changed since the 1970 s. Species diversity within aquatic communities is closely related to the trophic state of the water. Earlier, Gilyarov (1969) and Alimov (1990) demonstrated an inverse relationship between the values of the species diversity and biomass of different groups of planktonic and benthic invertebrates in lakes.

However, to draw adequate conclusions from the assessment of the ecological situation on the basis of composition, size and diversity of planktonic bacteria, algae and invertebrates, it must be considered that all these groups of living organisms characterize different aspects of ecosystem state and water pollution, and the rate of their response to pollution is also different.

\subsection{Bottom sediment indicators}

Bottom sediment represents the result of the accumulation processes of external chemical substances over a long time (Chen and Fan, 1998). The sediment should therefore be considered as a potential source of secondary pollution and as one of the indicators of the lake ecosystem's health (Martynova, 1988).
Due to the difficulty and complexity of sampling and monitoring the sediment, the following parameters can be considered: the concentration of heavy metals such as $\mathrm{Cu}$, $\mathrm{Zn}, \mathrm{Cd}, \mathrm{Pb}, \mathrm{Ni}, \mathrm{As}, \mathrm{Hg}, \mathrm{Cr}$, and nutrients including organic matter, TP, TN; the horizontal and vertical distribution of pollutants in sediment; exchange across the sedimentwater interface carried out by calculation of the value of phosphorus flux from the sediment to the overlying water and dimensionless indicators such as: (1) $L_{\mathrm{int}} / L$, where $L_{\text {int }}$ is the internal nutrient load on the lake $\left(\mathrm{g} /\left(\mathrm{m}^{2} \cdot \mathrm{a}\right)\right)$ and $L$ is the external nutrient load on the lake $\left(\mathrm{g} /\left(\mathrm{m}^{2} \cdot \mathrm{a}\right)\right)$; (2) $S / L$, where $S$ represents nutrient sedimentation on the lake bottom $\left(\mathrm{g} /\left(\mathrm{m}^{2} \cdot \mathrm{a}\right)\right)$; (3) $f$, relative input of benthic nutrient flux into the total nutrient storage in the water mass.

Because of the small volume of Wuli Lake, human activities affect the whole area. The pollution level of heavy metals was lower than the Environmental Quality Standard for Soils (GB15618-1995), when calculated with the $I_{\text {geo }}$ method (Shen et al., 2004). However, concentrations of organic matter, TN and TP were typically 2-5 times higher in sediments of the polluted area than in sediments of the unpolluted area in Taihu Lake (Fan et al., 1998a; Luo and Shi, 2003).

Eutrophication causes an increase in concentrations of nutrients and intensity of mass exchange across the sediment-water interface, enhancing a role of bottom sediments as an internal source of nutrients for the lake water mass. It can be seen in Fig.6 that nutrient ( $\mathrm{P}$ and $\mathrm{N}$ ) concentrations in sediments of Wuli Lake had increased since 1960, and the content of $\mathrm{N}$ and $\mathrm{P}$ rose to its peak value in the 1990s (Fan et al., 1998a; SIDRI, 2002; Shen et al., 2004; Yuan et al., 2002; Zhang and Wu, 2002).

Here we explain the indicators of the lake's state by the characteristics of "sediment-water" exchange for phosphorus. Studies of phosphorus exchange across the sediment-water interface showed that the value of release rates of phosphorus from sediments to overlying water varied from 2.75-3.14 $\mu \mathrm{g} /(\mathrm{g} \cdot \mathrm{d}$ ) (Yin et al., 1994; Wang et al., 1996). The amount of phosphorus flux from sediments to overlying water was from $0.584-2.05 \mathrm{mg} /\left(\mathrm{m}^{2} \cdot \mathrm{d}\right)$ in 1996 (Fan et al., 1998b). The increase of internal nutrient release means the decrease of nutrients sedimentation on the lake bottom. The $S / L$ value will be smaller when the external load entered into the lake is fixed.

The values of indicators addressed the development of eutrophication in Wuli Lake in the early 2000s were

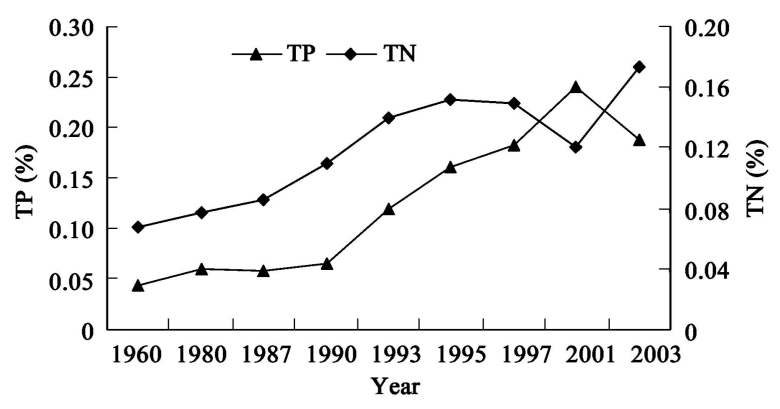

Fig. 6 Changes of nitrogen and phosphorus for bottom sediments in Wuli Lake. 
as follows: $L_{\mathrm{int}} / L=0.26 ; S / L=0.38 ; f=0.43$ (Environmental Monitoring Center of Wuxi City EPB; SIDRI, 2002). It was found that when $L_{\text {int }} / L>0.1$, the role of bottom sediments was significant in lake eutrophication (Martynova, 1988). As the eutrophication developed, the value of the $S / L$ ratio decreased. In lakes where the $f$ value exceeded 0.25-0.30, phosphorus input from the sediments became significant for the eutrophication process.

All indicators used during environmental assessment are shown in appendix.

\section{Discussion}

In principle, either single-criterion or multi-criteria auditing methodology can be adopted to perform a structured multidimensional quantitative analysis, noting that their goals and usefulness depends on the context. A single-criterion auditing approach is constructed mainly with monetary valuation while the multi-criteria approach extends this to include explicit environmental factors. Consequently there is a move towards a multi-criteria auditing approach in public and government sectors engaging in environmental protection. In this paper, several independent quantitative and qualitative evaluation criteria were constructed. However, a basic conviction underlying all approaches is that the use of several criteria is better for robust environmental auditing while facing multidimensional and ill-defined problems.

There are many evaluation methods for water environment, including driving force, state and response D-S-R indicators proposed by the CSD which were applied in Wuli Lake case. Results indicated that relationships existed among the three kinds of indicators. Values of driving force indicators showed an increasing trend during the last two decades (Table 1). The water environment status of Wuli Lake gradually deteriorated which was indicated by the concentration of faecal coliforms and BOD (Table 2). The governments have intensified their pollution control, environmental monitoring and management for Wuli Lake (Table 3). Consequently, the wastewater treatment rate increased. The D-S-R model shows water environment changes and pollution control of Wuli Lake. The model paid more attention to the macro trend of the study object, but it could not provide specific auditing criteria and reliable auditing suggestions for in-depth project evaluation. In order to fill the gap, four types of indicators of external pollution load, water quality, aquatic ecosystem and lake sediment were proposed in this paper. Various hydrological, chemical, biological and environmental parameters were used to estimate the values of different indicators for assessment of environmental status of the lake based on time series data sets for twenty years. Results showed that amount of external pollution load (TP) generally increased before 2001, and after that it became small (Table 4, Fig.3). Correspondingly, the water quality of Wuli Lake was improved (Fig.4). The aquatic ecosystem signified by phytoplankton and zooplankton was still in unbalance situation (Table 5, Fig.5). Lake sediment was the result of aggradation of the external pollution load, and it was also the internal pollution source of eutrophication in Wuli Lake. Parameters of bottom sediment indicated a sign of improvement recently.

\section{Conclusions}

An integrated evaluation framework has been proposed here by a combination of macro D-S-R indicators and four types of new indicators. This will be helpful for auditors to define auditing criteria, collect data, analyze and assess data and obtain specific auditing conclusions.

For the Supreme Audit Institution, water auditing is a new field. Several points should be taken into account if the multi-indicator framework is applied in more auditing cases which are as follows.

Gathering general data from various sources: water management dealt with many public sectors in China. Each sector had its own monitoring data. Auditors had great difficulty in collecting appropriate data to analyze and evaluate consistently. Even though the same auditing criteria and indicators are used, the auditing suggestions might be different if data sources are diverse. In this regard, the relevant departments should develop a uniform database at the beginning of decision making.

Flexibility of multi-indicator methodology: different environmental issues exist in various rivers and lakes. The multi-indicator framework is not a "dead" method. It should be adjusted to apply in different conditions. For example, if the multi-indicator framework is used to evaluate a river environment, the sediment indicators may not be necessary.

Integration with other indicators: water pollution and management is a complex issue. Effectiveness of water control project is influenced by social, economic and other factors. The multi-indicator methodology should be combined with social and economic evaluation indicators in order to put forward objective and reliable auditing recommendations.

Cooperation with multi-disciplinary experts: auditors are generally educated with accounting and economic backgrounds. They would face special barriers in the process of conducting water environmental auditing. Cooperation is needed between environmental auditors, environmental scientists and consultants for identifying auditing criteria and indicators, collecting auditing data, analyzing project effectiveness and obtaining auditing conclusions.

Acknowledgements: The authors would like to thank the National Audit Office of China (CNAO) and Chengdu Resident Office of CNAO for their support. We are grateful to anonymous reviewers for their comments.

\section{Appendix}

\begin{tabular}{lll}
\hline Type & Sign & Means \\
\hline $\begin{array}{l}\text { CSD indicators } \\
\begin{array}{c}\text { Driving force } \\
\text { indicators }\end{array}\end{array}$ & ID $_{1}$ & $\begin{array}{l}\text { Annual withdrawal of ground water } \\
\text { as a percentage of available water (\%) }\end{array}$ \\
\hline
\end{tabular}


$\underline{\text { Appendix continued }}$

\begin{tabular}{|c|c|c|}
\hline & $\mathrm{ID}_{2}$ & $\begin{array}{l}\text { Annual withdrawal of surface water } \\
\text { as a percentage of the surface } \\
\text { water resources }(\%)\end{array}$ \\
\hline & $\mathrm{ID}_{3}$ & $\begin{array}{l}\text { Domestic consumption of water } \\
\text { per capita }(\mathrm{L} /(\text { person } \cdot \mathrm{d})\end{array}$ \\
\hline \multirow{3}{*}{$\begin{array}{l}\text { State } \\
\text { indicators }\end{array}$} & $\mathrm{IS}_{1}$ & Surface water reserves $\left(10^{6} \mathrm{~m}^{3}\right)$ \\
\hline & $\mathrm{IS}_{2}$ & $\begin{array}{l}\text { Class of water quality by coli-index } \\
\text { (number of cell per liter) }\end{array}$ \\
\hline & $\mathrm{IS}_{3}$ & $\begin{array}{l}\text { Class of water quality by } \mathrm{BOD}_{5} \\
\text { in water bodies }\left(\mathrm{mg} \mathrm{O}_{2} / \mathrm{L}\right)\end{array}$ \\
\hline \multirow[t]{3}{*}{$\begin{array}{l}\text { Response } \\
\text { indicators }\end{array}$} & $\mathrm{IR}_{1}$ & $\begin{array}{l}\text { Total discharge of waste water } \\
\left(10^{4} \mathrm{~m}^{3} / \mathrm{a}\right)\end{array}$ \\
\hline & $\mathrm{IR}_{2}$ & Partly treated waters $\left(10^{4} \mathrm{~m}^{3} / \mathrm{a}\right)$ \\
\hline & $\mathrm{IR}_{3}$ & Non-treated waters $\left(10^{4} \mathrm{~m}^{3} / \mathrm{a}\right)$ \\
\hline \multirow{3}{*}{$\begin{array}{l}\text { External load } \\
\text { indicators }\end{array}$} & $\mathrm{IL}_{1}$ & TP load of basin area $\left(\mathrm{kg} / \mathrm{km}^{2}\right)$ \\
\hline & $\mathrm{IL}_{2}$ & TP load of surface water $\left(10^{-6} \mathrm{~kg} / \mathrm{m}^{3}\right)$ \\
\hline & $\mathrm{IL}_{3}$ & TP load per capita (kg/person) \\
\hline \multirow{2}{*}{$\begin{array}{l}\text { Water quality } \\
\text { indicators }\end{array}$} & $P$ value & Integrated index of water pollution \\
\hline & NI & Index of eutrophication \\
\hline \multirow[t]{3}{*}{$\begin{array}{l}\text { Biological } \\
\text { indicators }\end{array}$} & - & $\begin{array}{l}\text { The primary production and } \\
\text { decomposition rate of organic matter }\end{array}$ \\
\hline & - & $\begin{array}{l}\text { The Shannon-Wiener index of species } \\
\text { diversity of flora and fauna }\end{array}$ \\
\hline & IP & $\begin{array}{l}\text { The number of population densities } \\
\text { of different taxonomic groups } \\
\text { integrated index } \\
\text { of aquatic ecosystem }\end{array}$ \\
\hline \multirow{5}{*}{$\begin{array}{l}\text { Bottom sediment } \\
\text { indicators }\end{array}$} & $L_{\text {int }} / L$ & $L_{\text {int }}:$ the internal nutrients \\
\hline & & load on the lake $\left(\mathrm{g} /\left(\mathrm{m}^{2} \cdot \mathrm{a}\right)\right)$ \\
\hline & & $\begin{array}{l}L: \text { the external nutrients load on the } \\
\text { lake }\left(\mathrm{g} /\left(\mathrm{m}^{2} \cdot \mathrm{a}\right)\right)\end{array}$ \\
\hline & $S / L$ & $\begin{array}{l}S \text { : nutrients sedimentation on the } \\
\text { lake bottom }\left(\mathrm{g} /\left(\mathrm{m}^{2} \cdot \mathrm{a}\right)\right)\end{array}$ \\
\hline & $f$ & $\begin{array}{l}\text { Relative input of benthic nutrient } \\
\text { flux into the total nutrient storage } \\
\text { in the water mass }\end{array}$ \\
\hline
\end{tabular}

\section{References}

Alimov A F, 1990. Basic points of theory on functioning of aquatic ecosystems[J]. Gidrobiol Z (Kiev), 26: 3-13.

Andronikova I N, 1996. Zooplankton characteristics in monitoring of Lake Ladoga[J]. Hydrobiologia, 322: 173-179.

Bai G D, 1962. Limnology survey of Wuli Lake in 1951[J]. Zooplan Hydrobiol, 2(1): 93-100.

Bain M B, Loucks D P, 1999. Linking hydrology and ecology in simulations for impact assessment[C]. In: Proceedings of the 26th Water Resource Planning and Management Conference, American Society of Civil Engineers, Phoenix, Arizona, USA.

Bain M B, Amy L H, Daniel P L et al., 2000. Aquatic ecosystem protection and restoration: advances in methods for assessment and evaluation[J]. Environ Sci \& Policy, 3: S89-S98.

Balushkina E V, 1997. New integrated index for water quality evaluation based on structural characteristics of zoobenthos[C]. In: Sarkkula J (ed.), Proceedings of the Final Seminar of the Gulf of Finland Year 1996 (Helsinki, 17-18 March, 1997), Helsinki.

Bao J C, 1983. Plankton of Taihu Lake[J]. Freshwater Fish, 6: 33-38.

Bernard S D, Landis G H, 1997. Environmental auditing in management systems and public policy[J]. J Environ Econ Manage, 33: 331-346.

Bode R E, Novak M A, 1995. Development and application of biological impairment criteria for rivers and streams in New York State[M]. In: Biological assessment and criteria-tools for water resource planning and decision making (Davis W. S., Simon T. P., ed.). Florida: Lewis Publishers.

Chen H S, Fan C X, 1998. A way to comprehensively harness the water pollution in Taihu Lake: Sludge-dredging work for environmental purpose[J]. J Lake Sci, 10(suppl): 117-122.

Chen H S, 1999. Tough tasks remaining in the pollution control for the Lake Taihu[J]. China Water Resour, 3: 24-25.

Fan C X, Huang Y P, Bao J P, 1992. The evolution of nutrients and plankton in Taihu Lake[J]. Nanjing Institute of Geography Cellec, 9: 37-47.

Fan C X, 1996. Historical evolution of water ecological setting in Taihu Lake[J]. J Lake Sci, 8(4): 297-304.

Fan C X, Chen H S, 1998. On the problem of the eutrophication of Taihu Lake and its countermeasures of comprehensive control[J]. J Lake Sci, 10(suppl): 95-100.

Fan C X, Ji J, Sui G R, 1998a. Characteristics of the sludge storage in Taihu Lake and the special distributions of its main physical and chemical properties[M]. In: Res environ ecol Taihu Lake (Cai Q. M., ed.). Beijing: Meteorological Publishing House. 55-62.

Fan C X, Qing B Q, Sun Y, 1998b. Substance exchange across in Meiliang Bay water-sediment interface and Wuli Lake[J]. J Lake Sci, 10(1): 73-78.

GCMRC (Grand Canyon Monitoring and Research Center), 1999. The state of natural and cultural resources in the Colorado River ecosystem (Draft)[EB]. http://www.gcmrc.gov/ products/score/1999/score_99_water_quality.htm.

Gilyarov A M, 1969. Correlation between biomass and species diversity in a plankton community [J]. Zool Z (Moscow), 48: 485-493.

Goforth R R, 1999. Local and landscape-scale relations between stream communities, stream habitat, and terrestrial land cover properties[D]. Ph.D Dissertation. Field of Natural Resources, Cornell University, Ithaca, New York.

$\mathrm{Gu} \mathrm{G,} \mathrm{Lu} \mathrm{G} \mathrm{F,} \mathrm{2004.} \mathrm{On} \mathrm{the} \mathrm{integrated} \mathrm{control} \mathrm{of} \mathrm{water} \mathrm{environ-}$ ment of Wuli Lake, Lake Taihu[J]. J Lake Sci, 16(1): 56-60.

Harig A L, Bain M B, 1998. Defining and restoring biological integrity in wilderness lakes[J]. Ecol Appl, 8: 71-87.

INTOSAI Working Group on Environmental Auditing, 2001. Guidance on conducting audits of activities with an environmental perspective[M]. The Netherlands, The Hague: INTOSAI.

Jiao F, Li X, 2005. Study on eutrophication issues of Meiliang Bay in Taihu Lake[J]. Environ Pollut Prev, 27(3): 214-217.

Jin X C, 1990. Survey and research on the environment of Lake and Reservoir in China (1980-1985)[M]. Beijing: China Environmental Sciences Press.

Jin X C, Liu H L, Tu Q Y, 1990. Eutrophication of Lakes in China[M]. Beijing: China Environmental Sciences Press.

Jin X C, Tu Q Y, 1990. Survey criteria of eutrophication for the lake[M]. 2nd ed. Beijing: China Environmental Sciences Press.

Jing X C, 2001. Technology of lake eutrophication control and management $[\mathrm{M}]$. Beijing: China Chemical Industry Press.

Jones J, Robert H K, John N et al., 2001. Evaluation panel for the Grand Canyon monitoring and research center[R]. Integrated Water Quality Program (IWQP). 29.

Karr J R, Dudley D R, 1981. Ecological perspective on water quality goals[J]. Environ Manage, 5: 55-68.

Karr J R, 1991. Biological integrity: a long neglected aspect of water resource management[J]. Ecol Appl, 1: 66-84.

Kondratyev S, Gronskaya T, Ignatieva N et al., 2002. Assessment of present state of water resources of Lake Ladoga and its drainage basin using Sustainable Development indica- 
tors[J]. Ecol Indic, 2: 79-92.

Loucks D P, 1995. Developing and implementing decision support systems[J]. Water Resour Bull, 31: 571-582.

Loucks D P, Taylor M R, French P N, 1996. IRAS-interactive river-aquifer simulation model, program description and operating manual[M]. Department of civil and environmental engineering. Ithaca, New York: Cornell University.

Luo Q J, Shi J Z, 2003. Silt and ecological dredging of the Wulihu Lake[J]. Environ Monit Manage Tech, 15(1): 27-29.

Ma J J, 1997. Theory and method of environmental quality assessment $[\mathrm{M}]$. Xi' an: Xi' an Mapping Press.

Martynova M V, 1988. Regularities of the processes of accumulation, transformation and release of nitrogen and phosphorus compounds from the water bodies' sediments[D]. Doctoral Thesis, Hydrochim Institute, Rostov-on-Don. 47.

Ministry of Health of China, 1985. Sanitary standard for drinking water[S]. GB5749-85. Beijing, China.

Nanjing Institute of Geography, Chinese Academy of Sciences, 1965. Initial report of comprehensive survey on Taihu Lake[M]. Beijing: Science Press. 1-84.

Nanjing Institute of Geography, Chinese Academy of Sciences, 1982. Lakes records of Jiangsu Province[M]. Nanjing: Jiangsu Science and Technical Press. 132-148.

Novak M A, Bode R W, 1992. Percent model affinity: a new measure of macroinvertebrate community composition[J]. J North Amer Benthol Soc, 11: 80-85.

OECD Work on Sustainable Development, 1997. A discussion paper on work to be undertaken over the period 19982001[R].

Program of Work on Indicators for Sustainable Development of the Commission on Sustainable Development[R], 1995. Report of the Secretary-General to the CSD on the Chapter 40 of Agenda 21, 1995, Information for the DecisionMaking. (E/CN.17/1995/18).

Qin B Q, Luo L C, 2004. Changes in eco-environment and causes for Lake Taihu, China[J]. Quarter Sci, 24(5): 561-568.

SEPA (State Environmental Protection Administration of China), 2002. Environmental quality standard for surface water[S]. GB3838-2002. Beijing, China.

SEPA (State Environmental Protection Administration of China), 2004. Report on the State of the Environment in China 2003[R]. Environmental Information Center, Beijing.
Shen Y L, He P J, Shao L M, 2004. Characteristics of contaminated sediments in Wuli Lake of Tai Lake[J]. Resour Environ Yangtze Basin, 13(6): 584-588.

SIDRI (Shanghai investigation and design research institute), Water Resources Ministry of China, 2002. Feasibility report on integrated restoration program in Wuli Lake[R].

Tennant D L, 1976. Instream flow regimens for fish, wildlife, recreation and related environmental resources[J]. Fish, 1(4): 6.

US Fish Wildlife Service, 1980. New England flow recommendation policy[R]. US Fish and Wildlife Service, Northeast Regional Office, Hadley, Massachusetts.

Vollenweider R A, 1968. Scientific fundamentals of the eutrophication of lakes and flowing waters, with special reference to nitrogen and phosphorous as factors in eutrophication[R]. OECD Technical Report DAS/CSI/68, 27, OECD, Paris. 182.

Wang X R, Hua Z Z, Xu L et al., 1996. The effects of the environmental conditions on phosphorus release in lake sediments[J]. Environ Chem, 15(1): 15-19.

Wang Q G, Gu G, Yoshiro H, 2006. Toward integrated environmental management for challenges in water environmental protection of Lake Taihu Basin in China[J]. Environ Manage, 37(5): 579-588.

Yang L, Sun J, 2001. Phosphorus pollution investigation of Wuli Lake and Meiliang Lake[J]. Environ Monit Manage Tech, 13(6): 18-20.

Yang G S, Wang D J, Xu P Z et al., 2003. Tai Lake Basin: economic development, water environment and water disasters[M]. Beijing: Science Press.

Yin D Q, Qin Q R, Yan H, 1994. Effects of environmental factors on release of phosphorus from sediments in Wuli Lake[J]. J Lake Sci, 6(3): 240-245.

Yuan X Y, Chen J, Tao Y X et al., 2002. Spatial characteristics and environmental implication of nitrogen and phosphorus from bottom sediments in northern Taihu Lake[J]. Geochimica, 31(4): 321-328.

Zhang Q R, Wu Z M, 2002. Study on pollutants in Wuli Lake sediments[J]. Jiangsu Water Resour, 5: 27-28.

Zhu S P, 1959. Annual changes of several physical and chemical characters in the north water of Taihu Lake[J]. Ocean Limnol Stnica, 2(3): 146-162. 